Matko nasza,

opiekuj się nami,

przyjmij nas do Niepokalanego Serca Swego,

teraz i na wieki wieków. Amen.

Kraków

ANDRZEJ PIERÓG

\title{
REFLEKSJE NA POŻEGNANIE
}

Kraków, dziesiątego czerwca, wieczorem...

... ucichłe, przeżywające szok dziejowy, miasto -

Zniknęły gdzieś podekscytowane twarze,

oczy pełne łez,

usta napełnione chwałą Pańską,

obolałe od entuzjazmu ręce,

utrudzone ciągłą wędrówką w poszukiwaniu

uśmiechu, spojrzenia, gestu Pielgrzyma

znad Tybrowego brzegu, nogi ...

Wieczorny spacer ulicami zmęczonego i opustoszałego miasta

to rachunek sumienia.

Jedni nazywają to rewizją życia,

inni bilansem, podsumowaniem,

jeszcze inni mówią „o echach wizyty..."

Rachunek sumienia i żal,

a jednak żal ...

Puste okna przy Franciszkańskiej.

Tłumek ludzi jeszcze wpatrzonych $\mathrm{w}$ to miejsce, gdzie zwykł się ukazywać i wieczorami gawędzić z tłumami...

Wydawało się, że Stolica Apostolska przeniosła się na chwilę

do Krakowa. To nie złudzenie - to małe, zupełnie niedostrzegane dotychczas okno stało się na cztery dni amboną świata

dla Ojca świętego, który ze łzami żegna kolebkę swojego chrześcijaństwa.

Piotr m usi być w Rzymie.

Jan Paweł Drugi mus i pożegnać Kraków.

Tłumy kategorycznie wyznają: „Zostaniesz z nami!”

Transparenty? „Jesteś nasz!”

Piotr - Karol - Jan - Paweł musi pozostać w Rzymie,

- musi pozostać w naszych sercach,

w modlitwach,

w odrodzonym chrześcijaństwie -

Bo serca nasze to prawdziwa Stolica Piotrowa, w której Duch

Swięty wybrał sobie mieszkanie.

To niepojęte zjawisko rzuca człowieka na kolana

i wyrywa $z$ serca ...

naprawdę mocne postanowienie poprawy. 